\title{
Gênero e humor nas redes sociais: a campanha contra Dilma Rousseff no Brasil
}

\author{
Fagner Carniel ${ }^{1}$ (D) \\ Lennita Ruggi ${ }^{2}$ \\ Júlia de Oliveira Ruggi ${ }^{3}$
}

\begin{abstract}
Este artigo tem como corpus analítico um conjunto de 69 memes contrários a Dilma Rousseff que viralizaram na web brasileira entre junho de 2014 e agosto de 2016 e investiga os conteúdos mobilizados durante a campanha pública em favor do golpe parlamentar ocorrido no Brasil em 2016. A análise dessas produções, enquanto ferramentas nas disputas políticas que culminaram no golpe, é uma forma de interpretar as dinâmicas contemporâneas da política brasileira e o próprio lugar conferido à figura da mulher e do feminino no espaço público. O acervo coletado revela que a comicidade se constrói, em larga medida, sobre as desigualdades de gênero e, ao não problematizar tal enquadramento subjacente, o reforça. Enquanto estratégia analítica, propomos a classificação dos memes em quatro chaves interpretativas inspiradas na teoria política feminista: (1) despersonalização ou invisibilização; (2) humilhação ou ridicularização; (3) objetificação ou sexualização; e (4) agressão ou violência. Ao identificar os dispositivos que sustentam a comicidade a partir de parâmetros discursivos compartilhados, a pesquisa demonstra como a dimensão generificada do humor político mobilizou estereótipos sexistas e misóginos que não apenas atingiram Dilma Rousseff, mas reforçaram o próprio lugar simbólico das mulheres na política nacional.
\end{abstract}

Palavras-chave: Dilma Rousseff; gênero; humor; redes sociais; representação política

\section{Introdução}

A despeito das profundas desigualdades, diferenças e desconexões que estruturam a sociedade brasileira, a relação com as mídias digitais constitui uma prática cultural já arraigada no cotidiano de um enorme contingente de pessoas (Miskolci, 2011). Categorias analíticas como ciberativismo, ciberdemocracia e cidadania digital são exemplos de formulações teóricas recentes que procuram interpretar esse fenômeno e

\footnotetext{
1 Universidade Estadual de Maringá, Departamento de Ciências Humanas. Maringá, Paraná, Brasil.

E-mail: <fagnercarniel@yahoo.com.br>.

2 Universidade Federal do Paraná, Departamento de Educação. Curitiba, Paraná, Brasil.

E-mail: <lennitaruggi@hotmail.com>.

3 Universidade Federal do Paraná, Departamento de Ciência Política. Curitiba, Paraná, Brasil.

E-mail: <ju_pr@hotmail.com>.
} 
Ihe conferir sentidos particulares nos processos decisórios e eleitorais, e na própria configuração da agenda pública do país (Marques, Aquino e Miola, 2014). Tais formas de participação eletrônica pressupõem a apropriação de mídias por parte de indivíduos ou de coletivos que reconstroem o social na mediação com o universo on-line, produzindo manifestações variadas por meio da experimentação de tecnologias e de modelos sociais. Desse modo, problematizar o conteúdo das produções digitais que circulam todos os dias por milhares de computadores, tablets, notebooks e smartphones nos parece uma tarefa intelectual necessária se quisermos compreender as maneiras plurais pelas quais a vida política do país está sendo vista, percebida e representada nos anos recentes.

Nossa pesquisa se concentra em memes contrários a Dilma Rousseff que circularam nas redes sociais da web brasileira entre o período que envolveu a Copa do Mundo de Futebol Masculino da Fifa, realizada no Brasil, em junho de 2014, e o final da votação do impeachment no Senado federal, em agosto de 2016. Tais produções, com conteúdo e interesses variados, caracterizam-se pela autoria anônima e pela intenção cômica. O uso do humor contra a autoridade, inclusive sem autoria identificada, não é nenhuma novidade, mas os alvos, os formatos e os conteúdos diferem contextualmente (Berger, 2017). O que haveria de particular nas piadas e chacotas dirigidas à então presidenta? Que tipos de preconceitos ou significados os memes estariam disseminando?

Entendemos que o impeachment de 2016 foi um golpe parlamentar orquestrado com fortes dimensões de gênero, pois os esforços de oposição ao governo combinaram preconceitos e estereótipos sexistas para deslegitimar a imagem de Dilma. O objetivo deste artigo não é, todavia, abarcar uma suposta totalidade cultural para desvendar as razões e as estratégias primordiais do golpe. Nossa intenção é simplesmente a de construir um repertório denso e significativo, focado na multiplicidade de expressões do sexismo que pairam sobre a política brasileira, para assim (re)colocá-lo em discussão. A análise de memes depreciativos no contexto pré-golpe constitui, portanto, um método exploratório que não pretende elucidar o comportamento político brasileiro, mas sim problematizar aspectos contemporâneos de certo imaginário cultural generificado que se organiza no universo on-line/off-line.

Memes podem ser definidos como produções culturais que se difundem voluntariamente via e-mail, mensagens instantâneas, blogs ou redes sociais e ativam "piadas internas" através da recriação de outras produções já existentes por intermédio da imitação cômica, satírica ou irônica de seus elementos (Bauckhage, 2011). No circuito das redes sociais, a sua popularidade parece depender da enunciação eficaz de certo humor ou comicidade que permite a objetificação estereotipada com a finalidade de promover a brincadeira, o riso, o deboche, a zoeira ou o pastiche, dependendo para isso de um repertório comum que ancora os conteúdos transmitidos. Nos termos de Freire (2016, p. 37-38), "os memes passam a fazer parte de uma experiência compartilhada da construção política espontânea, que não passa pela mediação dos mass media, mas que, ao contrário, recebe contribuições de outros usuários". Cada meme pode ser 
compartilhado e modificado milhares de vezes, gerando efeitos diversos e potencialmente contraditórios. Em seu conjunto, entretanto, eles operam como narrativas que participam decisivamente da construção de imaginários, percepções, sensibilidades e representações coletivas acerca de determinados acontecimentos, relações e sujeitos sociais.

Como argumentam Chagas et al. (2017, p. 192), "memes políticos e sobre a política funcionam, nesse sentido, como materializações das trocas informais no ambiente das redes sociais on-line. Por meio deles, é possível captar as variações de humor da opinião pública ante o desempenho dos atores políticos em cena". Analisar o conteúdo que essas produções adquiriram entre 2014 e 2016 na esfera pública, como uma das ferramentas nas disputas políticas que culminaram no golpe, pode ser uma forma de interpretar as dinâmicas contemporâneas da política brasileira e o próprio lugar conferido à figura da mulher e do feminino em inúmeras narrativas que foram compartilhadas nas redes sociais. Assim, procuramos investigar como os memes satirizaram e desqualificaram Dilma e suas posições políticas - recorrendo para isso a um humor generificado que não seria acionável da mesma maneira caso ela fosse um homem.

A difusão de conteúdos contrários e depreciativos sobre Dilma não foi, evidentemente, propagada exclusivamente por memes digitais; pelo contrário, eles se articularam à própria campanha construída contra a ex-presidenta e contra o Partido dos Trabalhadores pelos meios de comunicação de massa hegemônicos ao longo das últimas décadas no país (Araújo, Costa e Fittipaldi, 2016; Rennó e Ames, 2014; Bezerra e Mundim, 2011; Miguel, 2010). No entanto, a maneira pela qual essas produções digitais circularam e seguem circulando na web brasileira, disseminando humor político e estereótipos de gênero, nos parece motivo de análises particulares, pois sua repercussão sinaliza a emergência de artefatos culturais que configuram práticas sociais articuladas em rede com ampla capacidade expressiva para afetar as percepções e as sensibilidades das pessoas em relação ao comportamento político.

A seguir, na seção "Dilma em memes: um itinerário de pesquisa nas redes sociais", explicitamos nossa estratégia de coleta do material empírico e dos ensaios realizados para a construção de uma tipologia. Na sequência, em "A sub-representação das mulheres na política brasileira", sintetizamos nosso embasamento teórico, inspirado na teoria política feminista. Dados contemporâneos e pesquisas sobre gênero na política brasileira, especialmente em relação à representação midiática, são mobilizados para contextualizar o debate e sustentar a interpretação exploratória dos memes. Na terceira seção, "A economia moral do sexismo na política brasileira contemporânea", analisamos o material empírico a partir de quatro categorias centradas nos dispositivos misóginos operacionalizados em diferentes conjuntos de memes, a saber: (1) despersonalização ou invisibilização; (2) humilhação ou ridicularização; (3) objetificação ou sexualização; e (4) agressão ou violência. Pretendemos argumentar que essa produção cultural típica das 
GÊNERO E HUMOR NAS REDES SOCIAIS: A CAMPANHA CONTRA DILMA ROUSSEFF NO BRASIL

redes sociais participa da produção de sentidos que reforçam a economia moral do sexismo no cotidiano político brasileiro.

\section{Dilma em memes: um itinerário de pesquisa nas redes sociais ${ }^{4}$}

Porque a raiva, assim como o riso, pode unir uma sala cheia de estranhos de um jeito único. Mas a raiva, ainda que ligada ao riso, não vai aliviar a tensão. Porque a raiva é uma tensão. É uma tensão tóxica e contagiosa. Seu único propósito é espalhar um ódio cego.

Hannah Gadsby (2017)

Humor é um objeto de pesquisa precário e melindroso. O riso nasce, com frequência, no inesperado de uma ruptura que, por ser ruptura, expande as possibilidades de compreensão e torna frágeis as tentativas de estabilização interpretativa. Ainda assim, como demonstra Gadsby (2017) em seu aclamado espetáculo Nanette, cabe investigar o humor como artefato cultural que gera solidariedade ou hostilidade, pois o riso pode favorecer a raiva reacionária e a manutenção das relações estruturais de poder. Nesse sentido, o documentário de Arantes, O riso dos outros (2012), é igualmente um recurso primordial para refletir sobre a cumplicidade entre humor e política, mas também sobre as possibilidades de reconstruir a graça para contestar e derrubar preconceitos.

Nossa pesquisa nasceu do incômodo de termos de assistir à campanha de difamação de Dilma Rousseff. A despeito da angústia em observar um golpe ser construído como uma tragédia anunciada, mesmo que não procurássemos consumir essa produção, a imersão no universo on-line brasileiro tornou impraticável escapar das piadas, dos posts, dos comentários, das polêmicas, dos tweets e, obviamente, dos memes contrários à presidenta. Não sendo possível nos desligarmos da maquinaria política furtiva operando no cotidiano, optamos por nos debruçar sobre ela. Começamos, em meados de 2015, a compartilhar entre nós algumas das imagens que nos pareciam mais grotescas, para dividirmos nossa repulsa. O adesivo-montagem com Dilma em lingerie usado em tampas de tanques de combustível foi provavelmente o primeiro meme que nos mobilizou, assim como a outras colegas, que também publicizaram sua aversão. De fato, embora nosso recorte metodológico não comporte essa dimensão, seria contraproducente ignorar que diversas peças difamatórias foram contestadas, originando críticas e refutações, inclusive em formatos de memes $^{5}$, que circularam amplamente nas

\footnotetext{
4 Agradecemos aos dois pareceres anônimos oferecidos pela revista Opinião Pública, que nos recomendaram expandir a seção metodológica do artigo e, dessa forma, nos ofereceram oportunidade de refletir sobre as dinâmicas confusas mas prolíferas da coleta de dados e estratégias analíticas.

5 Para um debate sobre memes feministas no contexto estadunidense, ver Rentschler e Thrift (2015).
} 
redes sociais. Por ironia, algumas dessas reações auxiliaram na divulgação de discursos e imagens degradantes.

Gradualmente nos demos conta de que os memes mereciam uma análise mais cuidadosa e organizada. Deter nossa atenção não foi, todavia, mais fácil do que tentar ignorar, pois essa produção cultural nas/das redes, mesmo se repetitiva e insistente, é ainda assim fugidia, dispersa e incomensurável. Em setembro de 2016 tínhamos aproximadamente 19 memes reunidos de maneira assistemática e uma primeira oportunidade de debater nossas observações ${ }^{6}$. Infelizmente, nessa altura alguns dos memes já não eram mais que memórias frágeis e não imediatamente acessíveis nas postagens do Facebook ou do WhatsApp. A efemeridade é, com efeito, uma das características desse formato expressivo. Decidimos, portanto, realizar uma varredura do universo on-line para criar um acervo mais compreensivo, delimitando como marcos temporais dois momentos importantes no contexto histórico-político brasileiro: a realização no país da Copa do Mundo de Futebol Masculino da Fifa (junho e julho de 2014) e a votação final do impeachment no Senado (agosto de 2016).

Vasculhamos diversas plataformas de informação para coleta manual (download), usando para isso: sites de busca na internet (Google e DuckDuckGo); versões digitais de mídias jornalísticas tradicionais, que, ao noticiarem e comentarem os memes, os mantinham acessíveis mesmo após o surto de viralização original ter se extinguido; e, finalmente, páginas de grupos favoráveis ao golpe no Facebook (Fora Dilma e Movimento Brasil Livre). Do total de 69 memes reunidos em outubro de 2016, 26 foram coletados no Facebook, 25 em compilações de veículos de informação (como jornais ou revistas), 14 em blogs, dois no Twitter e dois no WhatsApp. Rastreamos as datas de publicação e/ou compartilhamento para delimitar o recorte temporal. Não reivindicamos acesso à totalidade dos memes contrários a Dilma, mas o acervo final é consistente e está disponível para outras pesquisas. Como seria de esperar, nos deparamos com a presença de um mesmo meme em mais de uma plataforma e, nesses casos, demos preferência a registrar a primeira localização identificada, que, ressalte-se, não necessariamente revela nem a origem nem o principal ponto de divulgação.

O fato de termos angariado material de diferentes fontes tornou inviável contabilizar o número de curtidas ou compartilhamentos de cada meme, informação que poderia dar pistas sobre processos de consumo e viralização. Este artigo não abrange, com efeito, as maneiras como diferentes pessoas e grupos fizeram uso dos memes em suas práticas midiáticas, focando primordialmente o conteúdo e não a recepção. É possível argumentar, todavia, que, enquanto formato amplamente dependente da articulação em redes sociais, memes colocam em dúvida a pertinência da própria fragmentação metodológica que diferencia produção, conteúdo, emissão e recepção. O

\footnotetext{
6 Uma versão preliminar dessa pesquisa foi apresentada na Interdicisciplinary Conference on Gender and Women's Studies, em novembro de 2016, em Istambul. Voltamos a discuti-la no XXXI Congreso de la Asociación Latino Americana de Sociología (Alas), em dezembro de 2017, em Montevidéu.
} 
"público" (potencialmente também criador) está diretamente engajado no processo de difusão e o consumo se expressa, em larga medida, pelo compartilhamento do conteúdo, embaralhando momentos que são conceitualmente tratados como distintos. Conforme Burroughs (2013, p. 259) afirma, "[a]udiences, through memes, play an active role in remixing, re-articulating, and digesting popular culture. While circulating audience articulations of popular culture, memes also form a kind of distribution channel, which serves as a purveyor of political sentiments". É certo que formatos culturais recentes venham a demandar a gradativa reorganização das estratégias metodológicas dos estudos culturais. Nossa proposta é, todavia, mais modesta: propor categorias que ajudem a interpretar essa produção.

Chagas et al. (2017), tomando como inspiração as pesquisas de Shifman (2014), desenvolveram uma matriz taxonômica para memes baseada em seu enquadramento discursivo, dando origem a três macrocategorias analíticas que nomearam de (1) persuasivas, (2) de ação popular e (3) de discussão pública:

[O]s memes persuasivos têm o objetivo de despertar o engajamento (no próximo), os memes de ação popular têm o objetivo de demonstrar engajamento (ao próximo) e os memes de discussão pública têm o objetivo de familiarizar (o próximo e a si mesmo) junto ao universo da política (Chagas et al., 2017, p. 187).

Trata-se de uma classificação baseada nas motivações para a produção: oriunda ou de grupos políticos institucionalizados (persuasivos) ou de "cidadãos comuns" declarando filiação ideológica (ação popular) ou, ainda, de manifestações situacionais não necessariamente partidarizadas (discussão pública). Apesar de não termos elementos em nossa amostra para considerar cada peça no que diz respeito às motivações de produção, parece plausível observar que muitos dos memes contrários a Dilma no contexto prégolpe podem ser considerados do tipo persuasivo, mesmo quando elaborados por grupos políticos ou indivíduos não institucionalizados.

Uma vez construído o arquivo, algumas características de imediato chamaram nossa atenção. Em primeiro lugar, o fato de o crime de responsabilidade fiscal, que sustentou juridicamente o impeachment, não ser considerado digno de menção por nenhum dos memes. A seguir, a presença insistente de estereótipos sobre feminilidade (aparência física, sensualidade e maternidade). Finalmente, a recorrência de temas embasados na indústria do entretenimento. Todos os memes demandam, efetivamente, referências culturais prévias para sua interpretação, seja do contexto midiático e/ou político. Isso não é de surpreender, já que a própria definição de meme está atrelada à recriação ou reinterpretação de produções já existentes (Bauckhage, 2011). Chagas et al. (2017, p. 179) argumentam, com efeito, que: "como produto cultural, um meme depende de um repertório cultural extraído de relações sociais, memórias, referências históricas, geográficas, econômicas, e de aspectos conjunturais específicos". 
Nosso primeiro esforço de classificação considerou, portanto, os diferentes repertórios mobilizados para a criação de sentido. Dezesseis memes (quase um quarto do total) faziam referência a produtos culturais, como Jogos Vorazes, Teletubbies, Big Brother Brasil e Os Goonies; quatro, ao futebol; sete, à corrupção; e três, ao comunismo (se bem que em 18 memes, correspondentes a 26\%, Dilma traja roupas vermelhas, o que também poderia ser interpretado como alusão ao comunismo). A categorização pelos repertórios, se interessante, se mostrou ineficaz por não abranger a totalidade do acervo e porque grande parte dos memes acumula referências diversas. Um exemplo do tipo look-alike: a foto de Dona Clotilde (personagem de Chaves) com a legenda "Bruxa do 71" ao lado de uma foto de Dilma (vestida de vermelho) com a legenda "Bruxa do 171" (Figura 1). Embasado na indústria do entretenimento e citando o crime de estelionato de acordo com o Código Penal Brasileiro, esse meme é representativo da fecundidade do formato em deslocar e sobrepor sentidos de maneira a desafiar esforços de quantificação ou classificação.

\section{Figura 1}

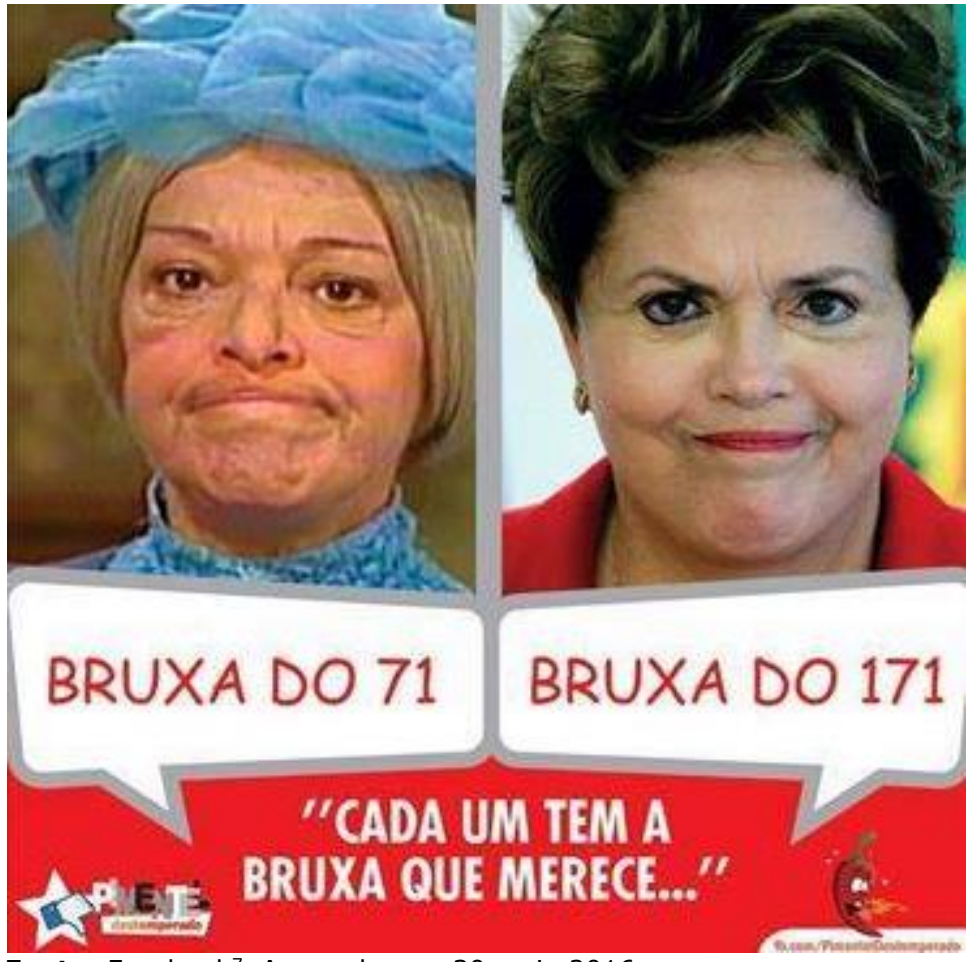

Fonte: Facebook?7. Acessado em: 30 maio 2016.

\footnotetext{
${ }^{7}<$ https://www.facebook.com/MovimentoForaDilma/photos/a.1375110796038221.1073741828.137509980 2705987/1494283384120961/?type=3\&theater $>$.
} 
$\mathrm{Na}$ sequência, categorizamos o acervo de acordo com o suporte imagético, considerando três formatos em que Dilma era diretamente retratada: ilustração, fotografia e fotomontagem; bem como a relação entre texto e imagem. No que se refere à ilustração (a), apenas quatro memes (5\%) têm desenhos como suporte, dos quais dois não incluem texto. Em três deles, Dilma compartilha a cena com políticos brasileiros, a saber: Tiradentes, Lula e Temer. Quanto à fotografia (b), 12 memes (17\%) constroem o humor a partir de foto não elogiosa da ex-presidenta, a cuja expressão desengonçada, mas sem alteração digital explícita, é adicionada uma frase de efeito. Tais memes são geralmente chamados de image-macro. São exemplos: "Dilma chora / e diz que tudo é golpe político"; "Vishi esqueci / de pagar esse juiz"; "Ja que impeachment Dilma não vai sair / uma renúncia serve"; e "Foi horrível / os deputados do impeachment pareciam a Alemanha". Em relação à fotomontagem (c), a maioria dos memes (23, o equivalente a $33 \%$ ) recorre a montagens fotográficas (os chamados exploitables), reinserindo imagens de Dilma em diferentes contextos: como segunda colocada em um concurso de beleza, dentro da boca de um canhão, no início de uma estrada, no fundo de um vaso sanitário ou recebendo o cartão vermelho de um juiz num campo de futebol. Ainda dentro do domínio da edição e manipulação de imagens, cinco memes metamorfoseiam Dilma em zumbi com pele azul ou demônio com língua bifurcada e chifres. Oito das fotomontagens são imagens sem texto. Essa tipologia se mostrou interessante para acessar as diferentes formas expressivas, mas não necessariamente o conteúdo dos memes e sua articulação com as relações de poder generificadas.

Um terceiro esforço de interpretação do acervo foi inspirado pelo trabalho de Ås (2004), que identifica sete técnicas de dominação para conservação de relações de subordinação. A tipologia de Ås foi elaborada a partir do estudo da interação com mulheres políticas no contexto norueguês. Não estando restrita à desigualdade de gênero, as técnicas são empregadas (consciente ou inconscientemente) em encontros face a face por alguém em posição de superioridade e servem para manter outras pessoas em situação de inferioridade, restringindo as opções de resposta ou ação dentro dos parâmetros aceitáveis de "cortesia" - sendo, portanto, difíceis de identificar ou contestar. Ås categoriza as técnicas de dominação como: (i) tornar invisível, (ii) ridicularizar, (iii) reter informações, (iv) condenar duplamente, (v) culpabilizar e envergonhar, (vi) objetificar e (vii) ameaçar com violência. O uso de tal tipologia revelou-se muito frutífero, pois ofereceu pistas sobre os fundamentos assimétricos de certos processos enunciativos e os efeitos que tais discursos produzem ao limitar as possibilidades de interpretação ou resposta. Contudo, a tentativa de "enquadrar" nosso acervo de memes nas sete classificações de Ås também se mostrou um exercício superficial e improdutivo devido às repetições e superposições de diferentes técnicas de dominação ${ }^{8}$.

\footnotetext{
8 Apesar disso, tanto a terminologia quanto a aspiração preventiva de Ås (cujo trabalho visa ajudar a identificar determinadas práticas para colocá-las em xeque) influenciam fortemente nosso esforço analítico.
} 
Apesar de esses exercícios preliminares de análise serem interessantes, nenhum deles oferecia elementos para aprofundar o funcionamento da comicidade generificada no acervo de memes contrários a Dilma. Para consolidar uma tipologia, foi necessário retomarmos nossa problemática ancorada nos dispositivos misóginos do humor em atuação nos memes. O incômodo que nos lançou no processo de pesquisa e no esforço de interpretação estava desde sempre relacionado à especificidade da articulação entre gênero e política na enunciação cômica. Isso exigia pensar nos preconceitos e estereótipos que sustentam as piadas e chacotas dos memes, o que demandaria contextualizar a representação das mulheres na política brasileira. Para tanto, recorremos à fortuna crítica da teoria política feminista, para a qual voltaremos agora nossa atenção.

\section{A sub-representação das mulheres na política brasileira}

[O]nde certos grupos sociais estruturais lograram dominar as discussões e as decisões políticas, suas perspectivas sociais geralmente definem as prioridades políticas, os termos nos quais elas são discutidas e a noção de relações sociais que enquadra a discussão. Ao mesmo tempo, essas perspectivas frequentemente não são reconhecidas como um modo específico de olhar as questões em pauta, mas tomadas como neutras e universais.

Iris Marion Young (2006, p. 174)

A questão da representação política é crucial nos debates feministas desde a chamada "primeira onda", que tinha como uma de suas prioridades ampliar os direitos políticos para mulheres. Todavia, como argumenta Miguel (2010), o acesso ao voto não foi suficiente para eliminar a assimetria de gênero em cargos eletivos, levando à defesa de ações afirmativas, implementadas em vários países. No Brasil, nem mesmo a lei que estabelece cotas de gênero para eleições parlamentares, promulgada pela primeira vez em 1995, resultou em uma transformação significativa da desigualdade entre mulheres e homens nas eleições. Vereadoras, deputadas e senadoras não ultrapassam, em média, $15 \%$ das composições legislativas nos estados e municípios. No pleito de 2014 , foram eleitas 43 mulheres para a Câmara Federal - o equivalente a 8,7\% de um universo de 513 representantes. No Senado, mulheres ocuparam aproximadamente $16 \%$ das cadeiras (13 de 81) na mesma legislatura.

Esse cenário não é exclusivo do Brasil (Rezende, 2017; Miguel, Marques e Machado, 2015), mas um desafio permanente das democracias liberais (Phillips, 2011). Parcela considerável da produção intelectual sobre o tema reconhece a necessidade de continuar a promover a discussão sobre a sub-representação feminina nos espaços de poder e indagar sobre os constrangimentos específicos que atingem mulheres em sua atuação política. Como adverte Young (2006), uma das características da hegemonia 
masculina é o fato de ela não ser reconhecida enquanto tal. Com efeito, nenhum dos memes contrários a Dilma tematizou a prevalência de homens no universo político eleitoral ${ }^{9}$.

De acordo com a literatura especializada, a sub-representação das mulheres na política brasileira expressa-se tanto quantitativa quanto qualitativamente. Questões consideradas "femininas" são desvalorizadas na agenda pública. Campos e Miguel (2008), por exemplo, argumentam que as pautas feministas estão excluídas do debate político no país. As demandas mais acaloradas são silenciadas para evitar conflitos, caracterizando uma verdadeira limitação imposta pelo próprio campo político, uma vez que representantes eleitos(as) dependeriam de alianças com grupos conservadores ou precisariam manter certa imagem construída durante a campanha. Campos e Miguel defendem que a ausência de temas como aborto, submissão familiar e desigualdades no mercado de trabalho ocorre porque deputadas não teriam interesse em assumir os riscos políticos de entrar nessas discussões.

Em pesquisas sobre capital social e representação política no Brasil, Sacchet (2009) aponta que gênero é uma categoria importante para investigar o engajamento cívico em diversos níveis de atuação. Segundo a autora, homens e mulheres tendem a participar de associações de cunho distinto: eles preferencialmente voltados para a esfera pública (como política, trabalho, lazer) e elas, a círculos relacionados à família e à comunidade. Nesse sentido, a participação feminina privilegia grupos homogêneos nos quais prevalecem relações pessoais de suma importância para a prática cotidiana, mas que são menos efetivas para angariar dividendos político-eleitorais. A análise de Sacchet permite identificar os processos por meio dos quais homens estão mais propensos a se inserir em redes impessoais e heterogêneas, cujas articulações financeiras e políticas são muito mais significativas para disputas nas urnas:

A sugestão aqui não é que os grupos nos quais as mulheres participam sejam menos importantes e que, portanto, o tipo de CS [capital social] que as mulheres acumulam é menos valioso do que o dos homens. Também não se trata de valorizar o político em detrimento do social, ou de recomendar que as mulheres adotem os mesmos métodos e estratégias de chegada ao poder que os homens. Trata-se, porém, de refletir sobre como as relações sociais tradicionais influenciam e são reproduzidas nos modelos atuais de participação e representação política, e quais suas consequências (Sacchet, 2009, p. 328).

\footnotetext{
9 A mesma dinâmica de ocultamento da exclusão, com o decorrente silenciamento de perspectivas, opiniões e interesses não dominantes, é operacionalizada em relação à desigualdade racial. Com efeito, a taxa de branquidade (Hasenbalg apud Rocha e Baptista Silva, 2006) dos memes coletados foi de $98 \%$, num total de 92 figuras humanas representadas. Infelizmente, não tivemos fôlego até o momento de aprofundar o debate em direção a questões interseccionais.
} 
Em levantamento comparativo do impacto das leis de cotas no Brasil e na Argentina, Araújo (2010) investiga o relativo insucesso das estratégias estatais de inclusão das mulheres no Poder Legislativo brasileiro. Dentre outros fatores, a autora argumenta que as linhagens geracionais são uma característica marcante, sendo a perpetuação de feudos e a operacionalidade da política como "propriedade familiar" uma prerrogativa com impacto significativo na escolha de candidaturas no Brasil. A despeito da existência de outras rotas de ascensão política não familiares, é relevante questionar o papel de um patriarca ou líder no engajamento político e, simultaneamente, como mulheres e homens articulam sua posição individual em relação à linhagem ou descendência política. Ao entrevistar deputadas e deputados federais, Araújo verifica que a influência do líder é mais marcante no discurso das mulheres, enquanto os homens não assumem tão claramente essa relação de patronagem, preferindo narrar sua atuação política como projeto pessoal relativamente autônomo. A associação entre as figuras públicas de Dilma e Lula é significativa nesse aspecto e foi, como mostraremos adiante, uma característica depreciativa reiterada em diversos memes analisados.

Uma das consequências mais relevantes do engajamento político diferenciado de mulheres e homens diz respeito à cobertura midiática. Segundo Finamore e Carvalho (2006), a disparidade de gênero é um dos principais mediadores da representação de candidatos(as) a cargos públicos. A cobertura jornalística associa mais imediatamente as candidatas a estereótipos do senso comum (a mulher restrita à vida privada), ao passo que os candidatos não são submetidos com tanta ênfase a marcas preconcebidas. "Isso sinaliza a presença de um discurso 'masculino' sobre as mulheres que vem sendo construído e mantido, enquanto os homens são muitas vezes preservados de marcas discriminatórias" (Finamore e Carvalho, 2006, p. 353). De acordo com os autores, uma candidata tem muito mais probabilidade de ser descrita em termos de sua vida pessoal, aparência e personalidade do que um candidato. O conjunto dessas análises empíricas reforça o argumento de Young (2006, 2012, 2014) sobre a reprodução de uma perspectiva hegemonicamente masculina que torna mais difícil a expressão de interesses e opiniões femininas, tratando-os como especificidades distantes da normalidade ou do "interesse comum".

Investigações de Miguel e Biroli (2009) demonstram que, quando eleitas, mulheres tendem a atuar em áreas consideradas de menor relevância, recebendo menos atenção jornalística, ao passo que homens, em geral, se concentram em temáticas que convergem para a promoção de suas carreiras políticas, nas quais a visibilidade da mídia é fator crucial. Economia e política, tidas como questões centrais, são tratadas pelos jornais como arenas tipicamente masculinas, reforçando a desigualdade entre homens e mulheres. Pesquisando em revistas e telejornais, Miguel e Biroli concluem que a cobertura televisiva acentua a sub-representação das mulheres na política, na medida em que há menos deputadas e senadoras presentes nos noticiários do que no próprio Congresso Nacional: 
GÊNERO E HUMOR NAS REDES SOCIAIS: A CAMPANHA CONTRA DILMA ROUSSEFF NO BRASIL

Como regra, as mulheres que ingressam na arena política não tardam a perceber o ônus que representa um enfrentamento aos estereótipos de sexo. Os meios de comunicação, o Estado, os partidos e o próprio eleitorado mostram-se mais confortáveis diante de mulheres que correspondem àquilo que se espera delas, e esse é um fator que pesa nas suas chances de êxito eleitoral e político (Miguel e Biroli, 2009, p. 70).

Além disso, os parâmetros de julgamento não são os mesmos para políticos e políticas. A vida privada/familiar e o trato social são enfatizados no caso feminino, em conformidade com as expectativas de "polidez" e "cuidado" das relações sociais generificadas; ao passo que "habilidade técnica" e "firmeza" são as qualidades masculinas tipicamente destacadas. Em paralelo, a dimensão corporal é marcante na representação das mulheres, sendo esse aspecto extensivo às candidatas ou às eleitas sem contrapartida nesse aspecto com os corpos de políticos homens. Nos memes que apoiaram o golpe de 2016, o corpo, a aparência e o comportamento de Dilma são, com efeito, julgados de acordo com parâmetros generificados e com base em padrões de beleza excludentes.

Nosso artigo participa dos esforços analíticos aqui sintetizados problematizando o universo on-line, no qual estão presentes diversos dos traços identificados pelas pesquisas sobre mídia tradicional. Com efeito, a análise empírica que apresentamos a seguir é construída sobre o repertório feminista de crítica social e, nesse sentido, pretende ajudar a reconhecer, nomear e, em última instância, frustrar os efeitos perniciosos de determinados discursos. Ao denunciar os constrangimentos específicos (porque misóginos) dos memes sobre Dilma nas redes sociais esperamos colaborar nos debates sobre a sub-representação das mulheres nos espaços de poder.

\section{A economia moral do sexismo na política brasileira contemporânea}

A piada preconceituosa se ancora em determinados valores, por definição: preconceitos solidificados na sociedade. Então é fácil fazer piada com esses estereótipos. Por que eles estão prontos para você. Desmontá-los é muito mais difícil.

Ideber Avelar ${ }^{10}$

Indagar sobre a especificidade do humor generificado contra Dilma Rousseff exige pensar como as piadas e chacotas reproduzem preconceitos. Identificamos quatro principais estratégias discursivas de depreciação misógina, nomeadamente: (1) despersonalização ou invisibilização; (2) humilhação ou ridicularização; (3) objetificação

\footnotetext{
10 Em entrevista ao documentário O riso dos outros (Arantes, 2012).
} 
ou sexualização; e (4) agressão ou violência ${ }^{11}$. Elas articulam imaginários estereotipados de feminilidade, que são reforçados por sustentarem (e ocultarem) um modo comum de suscitar comicidade. Nesse sentido, replicamos as recomendações metodológicas de Shifman (apud Chagas et al., 2017), que propõe investigar memes não como unidades isoladas, mas enquanto coleções ou conjuntos semânticos. Na sequência consideramos cada uma das categorias em detalhe, apresentando memes que exemplificam o dispositivo discursivo identificado.

\section{Despersonalização ou invisibilização}

A primeira categoria congrega um conjunto de manifestações que deslegitimam o estatuto político e a própria existência de Dilma como ser autônomo, tornando-a invisível ou insignificante. Ao enunciar a relação dela com o ex-presidente Lula como sendo de dependência ou mesmo de completa identidade, tais memes ecoam a advertência feita por Araújo (2010) sobre a tendência a supervalorizar a importância do patriarca ou líder político nas carreiras eleitorais das mulheres. Aproximadamente $17 \%$ do arquivo (ou 12 peças) recorrem a essa estratégia discursiva.

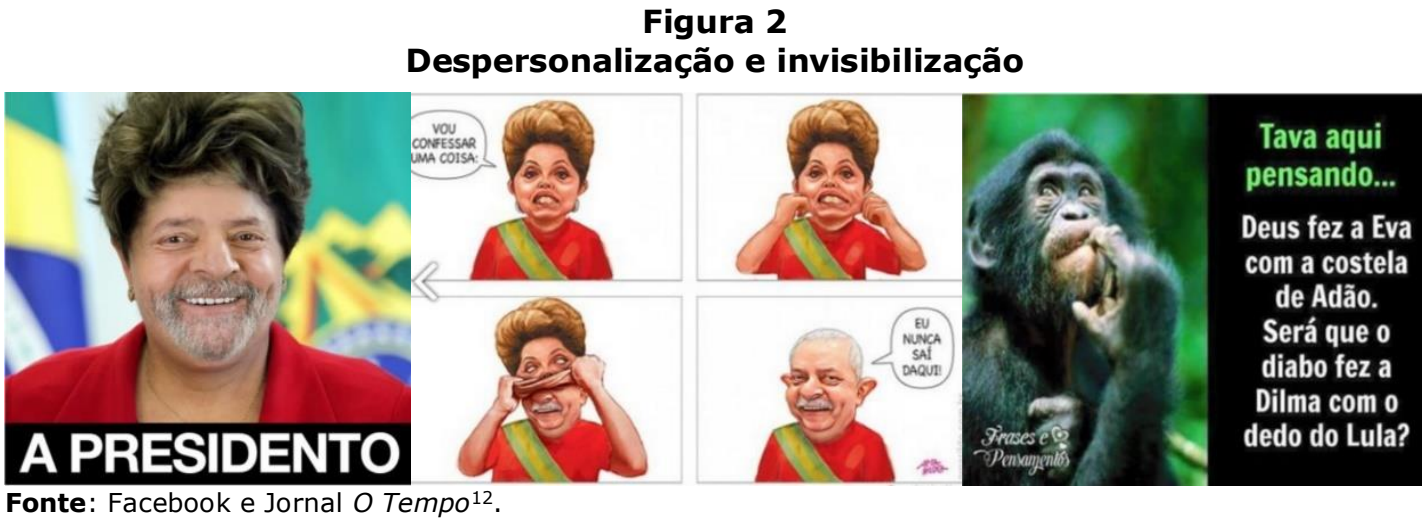

Os memes apresentados na Figura 2 são exemplos dessa categoria. Na primeira imagem, características de Dilma (o terno vermelho, o corte de cabelo) são mescladas ao rosto de Lula, enquanto o texto faz referência à polêmica relativa ao termo "presidentX". Quando Dilma assumiu o cargo, procurou "feminilizar" a grafia, exigindo ser chamada de "presidenta"; recomendação que, diga-se de passagem, não foi seguida pelos meios de

\footnotetext{
11 Como indicado anteriormente, essa tipologia tem como inspiração principal o trabalho de Ås (2004), Finamore e Carvalho (2006), Miguel e Biroli (2009) e Araújo (2010).

12 Disponível em: <http://www.otempo.com.br/capa/pol\%C3\%ADtica/memes-sobre-momentopol\%C3\%ADtico-do-pa\%C3\%ADs-invadem-as-redes-sociais-1.1260061 >; <http://www.vistadireita.com.br/blog/os-melhores-memes-da-semana/>;

<https://www.facebook.com/ForaDilma-855493611170222/?ref=ts\&fref=ts>. Acesso em: 20 ago. 2016.
} 
comunicação opositores ao seu governo. No meme considerado, essa controvérsia é tomada de forma irônica, criando um oximoro de gênero que é destacado pela sobreposição do rosto de Lula em Dilma. A imagem ironiza uma representação por excelência da galeria presidencial (com a bandeira nacional ao fundo), despersonificando Dilma. O segundo meme atinge o mesmo efeito ao representar Dilma como uma máscara que, ao ser retirada, revela Lula, ilustração acentuada pelo texto: "Vou confessar uma coisa... Eu nunca saí daqui!". O último meme da Figura 2 caçoa do dedo mínimo ausente na mão esquerda de Lula, perdido em um acidente de trabalho, remontando a um imaginário bíblico segundo o qual as mulheres são uma versão secundária da humanidade, cujo protótipo é masculino.

Humilhação e ridicularização

Não seria exagero afirmar que todos os memes contrários a Dilma têm potencialmente a intencionalidade de humilhar e ridicularizar, na medida em que expressam o anseio político de deslegitimar a autoridade usando do humor ou do grotesco para esculhambar e escrachar. São, como já foi indicado, memes persuasivos (Chagas et al., 2017) e, nesse sentido, não necessariamente generificados. Mas o acervo demonstra correlações com determinados mecanismos do machismo e da misoginia já identificados pela crítica feminista, que enquadram a feminilidade como desprovida de inteligência ou racionalidade, ligada ao sobrenatural ou propensa ao descontrole emotivo (Beauvoir, 1960). Dentro da categoria humilhação ou ridicularização, identificamos três subdivisões: imbecilização, demonização e hipersensibilização. A reiteração de imagens negativas sobre feminilidade é parte do que Young (2014) descreve sobre a manutenção das estruturas de poder excludentes calcadas em interesses, opiniões e perspectivas normalizadas e universalizadas, ignorando a história de desigualdades estruturais que reproduzem a baixa representatividade das mulheres na política brasileira.

\section{Figura 3}

Humilhação ou ridicularização - Imbecilização

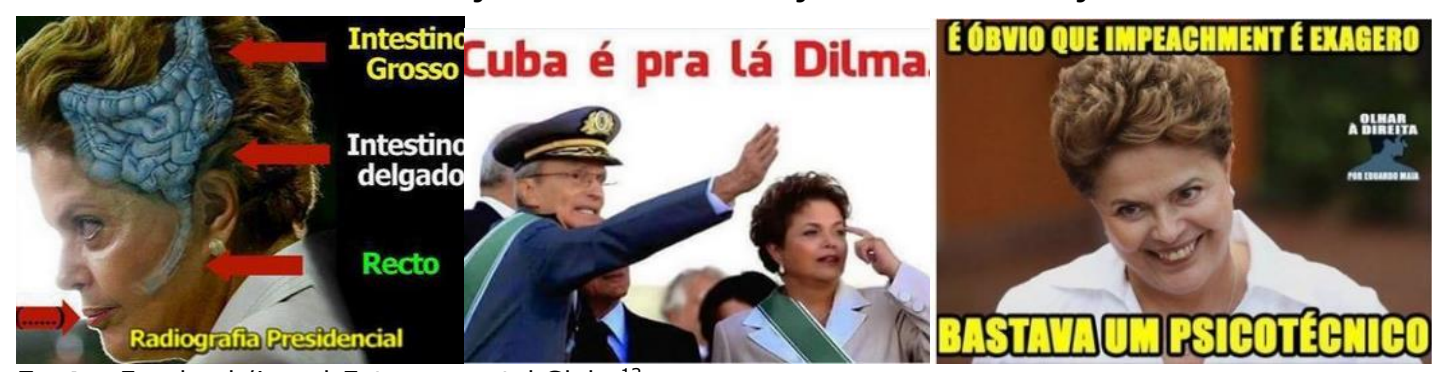

Fonte: Facebook/jornal Extra no portal Globo ${ }^{13}$.

13 Disponível em:

<https://www.facebook.com/MovimentoForaDilma/photos/a.1375110796038221.1073741828.137509980

2705987/1386953714853929/?type=3\&theater > ; <http://extra.globo.com/noticias/brasil/guerra-dos- 
Figura 4

Humilhação ou ridicularização - Demonização
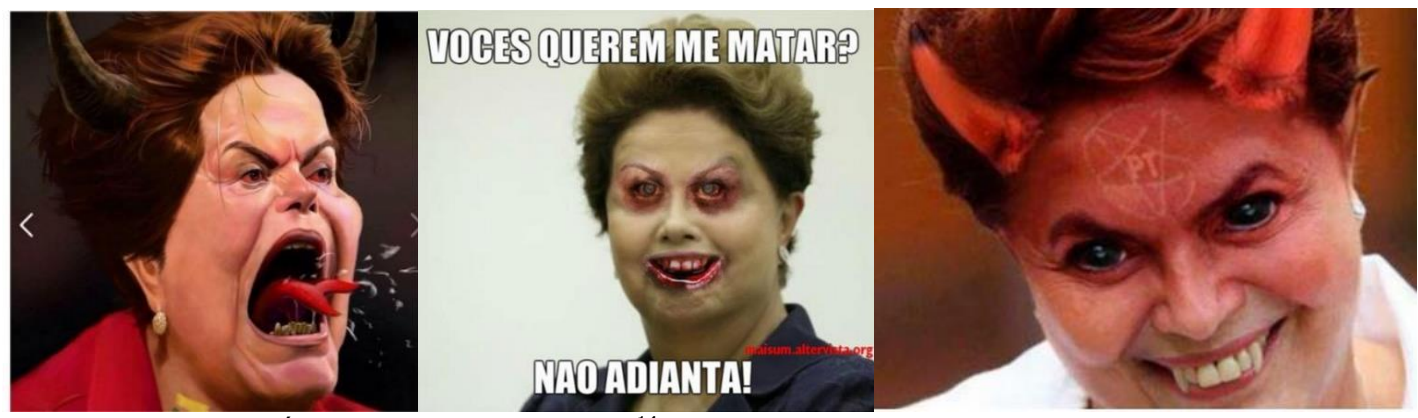

Fonte: Facebook/notícias $A$ tarde do portal UOL ${ }^{14}$.

Figura 5

Humilhação ou ridicularização - Hipersensibilização

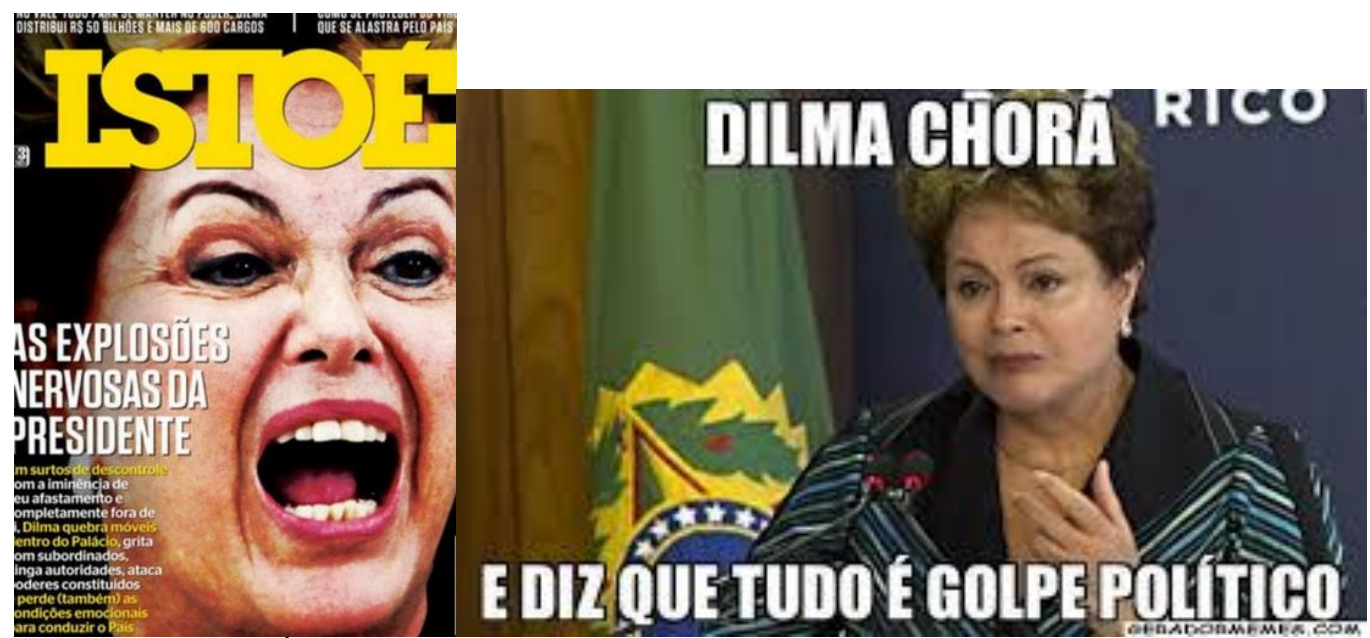

Fonte: Revista Istó́ e Facebook ${ }^{15}$.

Dentre os 18 memes ( $26 \%$ do total) que recorrem à imbecilização, três estão retratados na Figura 3. De diferentes maneiras eles desautorizam a capacidade cognitiva de Dilma, comparando seu cérebro ao sistema excretor; sugerindo incapacidade de se orientar geograficamente e insinuando que ela não seria aprovada em um teste

memes-sobre-votacao-do-processo-de-impeachment-no-senado-divide-internautas-19276961.html>.

Acesso em: 15 jul. 2016.

Disponível em: <https://www.facebook.com/MovimentoForaDilma/>. Acesso em: 20 ago. 2016.

14 Disponível em:

<https://www.facebook.com/MovimentoForaDilma/photos/a.1375100469372587.1073741825.137509980 2705987/1670476303168334/?type=3\&theater>; <http://maiszero.blogspot.com.br/2015/03/meme-dadilma-zumbi.html>. Acesso em: 15 jul. 2016.

Disponível em: <http://atarde.uol.com.br/politica/noticias/1770428-dilma-e-temer-sao-alvos-de-memessobre-sexta-feira-13>. Acesso em: 20 ago. 2016.

15 Disponível em: <istoe.com.br/edicao/894_AS+EXPLOSOES+NERVOSAS+DA+PRESIDENTE/> ;

<https://www.facebook.com/MovimentoForaDilma/>. Acesso em: 30 maio 2016. 
psicológico. A Figura 4 reúne memes que demonizam Dilma e ecoam séculos de acusações reiteradas de bruxaria ou pactos demoníacos enquanto estratégia política do mundo ocidental ou ocidentalizado para manter processos de dominação (Federici, 2004). Finalmente, memes que enfatizam uma suposta dimensão hipersensível, emotiva ou descontrolada de Dilma estão dispostos na Figura 5. A capa da revista IstoÉ, que viralizou como meme após sua publicação em abril de 2016, gerou debates organizados sob a hashtag \#IstoÉMachismo, tal como analisou Lopes (2016).

Bem-sucedidos como sejam em sobrepor referências diversas (anatomia humana, socialismo cubano, provas do Detran, tecnologias de fotomontagem digital para criação de zumbis), o mecanismo subjacente desses memes se limita a ecoar estereótipos habituais da misoginia para humilhar e ridicularizar. Cabe aqui retomar o argumento já citado de Miguel e Biroli (2009, p. 70), segundo o qual "mulheres que ingressam na arena política não tardam a perceber o ônus que representa um enfrentamento aos estereótipos de sexo".

\section{Objetificação e sexualização}

A terceira categoria identificada diz respeito a processos de objetificação ou sexualização. Objetificar uma pessoa é fazer equivaler aparência e valor humano, colocando em primeiro plano o julgamento estético e a "qualidade do panorama" oferecido (Berger, 1999). O imaginário de sexualização das mulheres, típico do repertório imagético ocidental e ocidentalizado, está sendo denunciado pelo menos desde a segunda onda do movimento feminista, em meados da década de 1960. Intimamente relacionado com a cultura do estupro, com a competitividade entre mulheres pela atração dos olhares e da atenção masculina e com a abjeção a corpos de mulheres que não se conformam aos padrões de beleza consagrados (Bordo, 1999), esse dispositivo humorístico traz implícito o registro da sexualidade como exercício de poder viril. 
Figura 6 Objetificação e sexualização

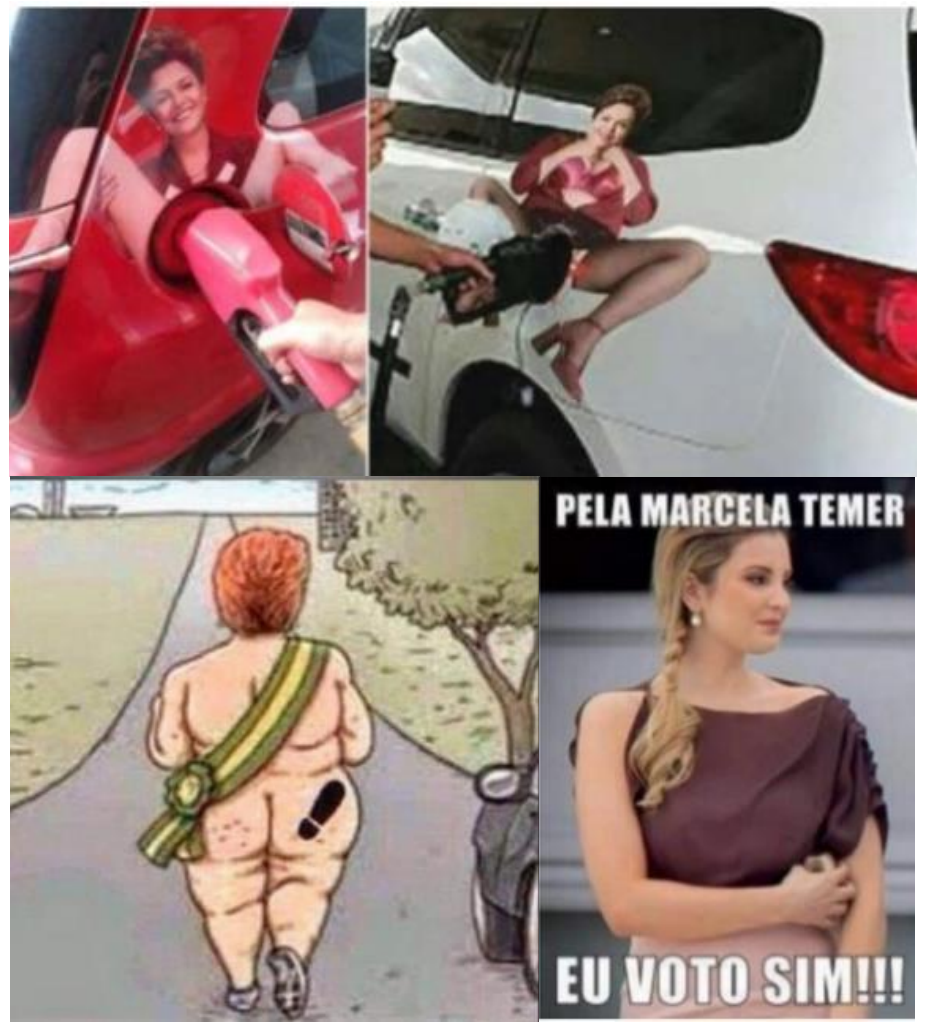

Fonte: WhatsApp e Facebook ${ }^{16}$.

A Figura 6 apresenta exemplos de memes que recorrem à objetificação ou sexualização enunciativa, uma amostra do total de oito produções (ou $11 \%$ do acervo coletado). O primeiro deles viraliza fotografias de adesivos da presidenta fetichizada com as pernas abertas, salto alto e lingerie - colados no tanque de combustíveis de automóveis ${ }^{17}$. No segundo, um desenho de Dilma de costas e nua, trajando apenas a faixa presidencial e um "pé na bunda", recorre ao deboche de corporalidades que não se conformam aos padrões de beleza estereotipados e excludentes. Essa forma de depreciação estética é potencializada ao compararmos este e o meme seguinte com a imagem de Marcela Temer, a esposa do então vice-presidente, o qual assumiria o cargo após o golpe. Fazendo referência à votação do impeachment no Congresso Nacional,

\footnotetext{
16 Disponível em: <https://www.infomoney.com.br/blogs/fora-do-mercado/blog-daredacao/post/4134933/adesivo-com-dilma-sendo-penetrada-por-bomba-levanta-questao-isso > ; <http://www.alertatotal.net/2016/04/impeachment-avanca-dilma-reage-ou.html> ; <https://www.facebook.com/MovimentoForaDilma/>. Acesso em: 30 ago. 2016.

17 A imagem gerou diversas reações e a então ministra da Secretaria de Política para as Mulheres, Eleonora Menicucci, formalizou denúncia de difamação, interrompendo a comercialização do adesivo.
} 
durante o qual deputados e deputadas favoráveis ao afastamento da presidenta justificaram o voto "sim", o terceiro meme pretensamente valoriza a beleza de Marcela Temer ao reforçar a objetificação feminina. O conjunto de memes objetificantes ou sexualizantes ecoa as evidências levantadas por Miguel e Biroli (2009) no tocante a mídias jornalísticas tradicionais, pois também nos memes contrários a Dilma Rousseff se observa a ênfase na dimensão corporal das mulheres políticas.

\section{Agressão ou violência}

A última categoria diz respeito à vulgarização de representações ligadas à violência física contra mulheres. São memes que usam da agressão e suas sequelas (olhos roxos, arranhões, escoriações e sangue) ou de ameaças de violência como mote para satirizar Dilma. Doze dos memes coletados, o equivalente a $17 \%$ do total, podem ser enquadrados nessa estratégia enunciativa.

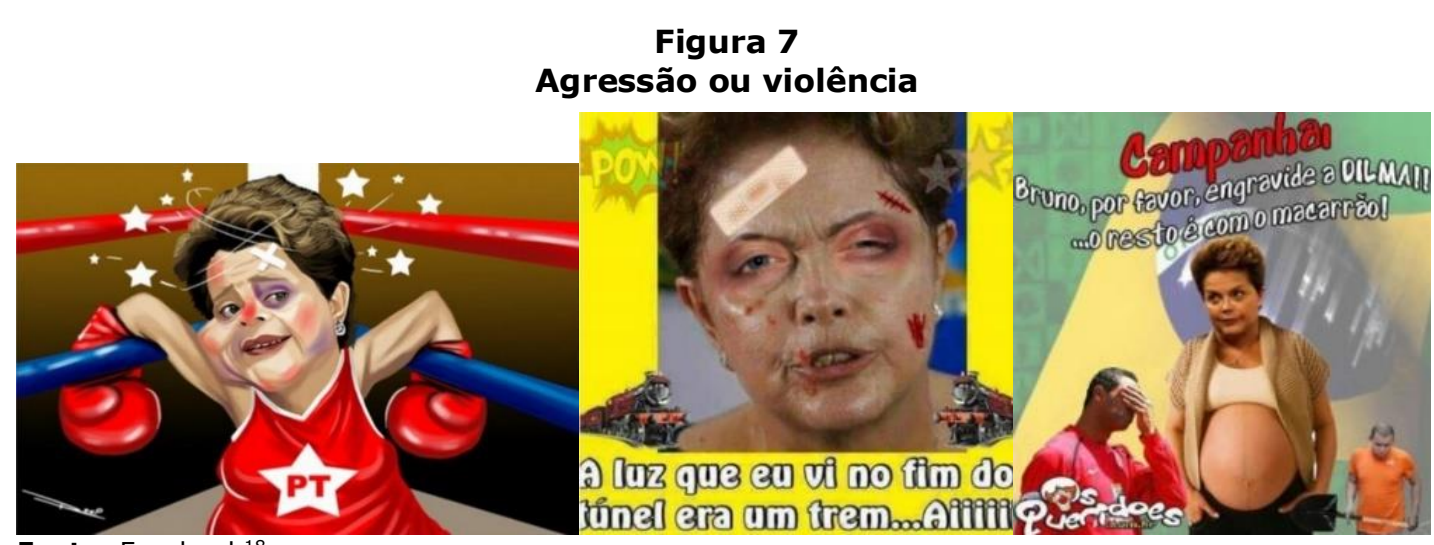

Fonte: Facebook ${ }^{18}$.

A primeira imagem da Figura 7 transfigura as disputas político-partidárias em relações de força que nocauteiam o governo do PT (Partido dos Trabalhadores) e ferem sua representante, Dilma Rousseff. No segundo meme, o rosto de Dilma é transfigurado por marcas de violência. No último meme, a referência mobilizada é o caso do ex-goleiro de futebol Bruno Fernandes e de seu colega Macarrão (Luiz Henrique Romão), condenados pelo sequestro, cárcere privado e homicídio de Eliza Samudio em 2013, modelo que estava grávida de Bruno.

O desconforto que causa encarar a transformação do assassinato de uma mulher em chacota à autoridade de Dilma não pode ser ofuscado pelo fato de que o humor é uma das formas de redenção que apaziguam as tensões sociais ao evocar um mundo de

18 Disponível em: <https://www.facebook.com/ForaDilma-855493611170222/?ref=ts\&fref=ts> ;

<https://www.facebook.com/ForaDilma-855493611170222/?ref=ts\&fref=ts>. Acesso em: 20 ago. 2016.

<https://pt-br.facebook.com/brunobitencourtdematos/>. Acesso em: 20 ago. 2016. 
regras próprias (Berger, 2017). No entanto, o que está em causa aqui é menos a condenação moral de quem produziu ou difundiu memes misóginos do que o reenquadramento destes na tradição da crítica feminista e, então, a identificação das coordenadas de entendimento que tornam tal comicidade possível.

Nas categorias despersonalização ou invisibilização, humilhação ou ridicularização e objetificação ou sexualização, encontramos diálogo acentuado com aspectos debatidos na teoria de ciência política feminista (Araújo, 2010; Young, 2006; Miguel e Biroli, 2009), seja pela questão do patriarcado, ou pelo julgamento das mulheres em termos de aparência, atributos considerados femininos e expectativa de determinados comportamentos. Já na categoria que trata de agressão ou violência, nos vimos diante de um tema que, em primeira análise, parece ainda ter margem para pesquisa e debate com aprimoramento do arcabouço teórico que correlacione mulheres na política e violência contra mulheres. O que os memes contra Dilma inseridos nessa categoria demonstram é que as mulheres políticas não estão imunes às ameaças de agressão, justamente por ser um ponto que transpassa toda a vivência misógina. Diante disso, defendemos que a ameaça de violência (que por si só já é uma violência) deve ser incorporada nos debates que interseccionam gênero e instituições políticas para incluir esse aspecto da teoria feminista.

\section{Considerações finais}

The question is not "will there be memes" but "which memes will they be". Philips e Miltner ${ }^{19}$ (apud Rentschler e Thrift, 2015, p. 334)

O humor político praticado nas redes sociais contra Dilma Rousself entre os anos de 2014 e 2016, para nos restringirmos apenas ao período estudado, sem dúvida é atravessado por estereótipos sexistas e misóginos. Tais estereótipos participaram da campanha pública que legitimou socialmente o golpe contra Dilma, conferindo certo destaque às redes sociais. Suas consequências sobre as sociabilidades cotidianas, no entanto, não podem ser reduzidas a um único sentido. Ainda que o cômico nessas produções possa ser considerado como uma expressão representativa de valores e práticas sexistas, o riso também encerra uma resposta pronta e fluida à rigidez das relações generificadas. O problema, contudo, parece ser aquele que Bergson (2004, p. 2) denunciou ao analisar o cômico na vida moderna: "a indiferença é seu meio natural". Ou seja, os risos potencialmente desencadeados pelos memes que ridicularizaram Dilma a partir de certos estereótipos podem ser considerados como gestos sociais que despertam insensibilidade diante da violência estrutural das relações de gênero no país. Mas esses memes também geraram reações diversas de risos.

19 W. Philips e K. Miltner, "The meme election: clicktivism, the buzzfeed effect and corporate memeJacking", 2012. 
No processo coletivo de circulação de sentidos concorrentes, também este artigo é uma produção cultural que multiplica as interpretações através da recriação de memes, recontextualizando-os por intermédio de triagem, análise e crítica de seus conteúdos. Nosso esforço analítico foi o de identificar conteúdos misóginos do humor para, ao tipificar e nomear os formatos enunciativos, construir repertórios que ajudem a interpretar produtos culturais. Consolidamos, com base no acervo da teoria política feminista, quatro categorias classificatórias: (1) despersonalização ou invisibilização; (2) humilhação ou ridicularização (incluindo imbecilização, demonização e hipersensibilização); (3) objetificação ou sexualização; e (4) agressão ou violência. Não é garantido que identificar matrizes de significado que sustentam o conteúdo dessas produções culturais digitais, por si só, ajude a arruinar a eficácia cômica de um meme misógino, mas é nosso anseio pelo menos desestabilizar a pretensa normalidade ou inocência que parece reger grande parte do humor generificado. Nesse sentido, este artigo faz parte de um esforço coletivo. Até porque, apesar de não ter sido contemplada no escopo da presente pesquisa, a produção feminista tem sido palpitante (e sofisticada) nas redes sociais - criticando enquadramentos machistas, contestando apelos misóginos, reivindicando retratação, deslocando os parâmetros de (des)legitimação e criando formas alternativas de humor.

O que parece mais perturbador e, ao mesmo tempo, extraordinário nos universos on-line/off-line contemporâneos é a convivência, num mesmo instante criativo, da crítica feminista e da gargalhada misógina. Nas disputas por sentido, a simultaneidade de gramáticas divergentes não deveria nos impedir de reconhecer que a circulação dos significados e das posições em disputa é coconstituída. Mais do que interpretar o que cada meme expressa ou deixa de expressar, essa investigação procurou compreendê-los no interior dos processos de apropriação e de recriação que eles suscitam em seu conjunto. Trata-se, evidentemente, de um uso social que está relacionado com possibilidades desiguais de acesso à internet, com a natureza técnica das diferentes mídias digitais e com as habilidades heterogêneas de usuários para produzir e decodificar os conteúdos difundidos. Contudo, trata-se também de uma experiência subjetiva que as pessoas mantêm com outras, e consigo mesmas, através de suas máquinas e interfaces.

Como já observou Certeau (1996), a mudança cultural se manifesta principalmente nas incontáveis maneiras de fazer e desfazer as atividades ordinárias, pois são elas as principais responsáveis pelas transformações nos afetos e nas sensibilidades por meio das quais tomamos consciência dos aspectos plurais e conflitivos da realidade em que vivemos. Essas práticas cotidianas hoje ocorrem "dentro" e "fora" das telas de computadores, de tablets e de smartphones, gerando produtos, performances e narrativas que atravessam descontinuamente as relações on-line/off-line. Os memes são um desses produtos digitais que propiciam performances, marcam posições ideológicas e ensejam narrativas coletivas que concorrem para desencadear os processos de representação política no Brasil. Portanto, refletir sobre o modo como eles 
FAGNER CARNIEL; LENNITA RUGGI; JÚLIA DE OLIVEIRA RUGGI

participam da vida política e como afetam as sensibilidades e as percepções das pessoas não é um desafio meramente metodológico, mas também ético e epistêmico, já que permite entrever as micropolíticas que emergem da economia moral da pretensa multidão.

\section{Referências bibliográficas}

ARANTES, P. (dir.). O riso dos outros. Documentário. Prod. e exib. TV Câmara. Brasil, 2012 (52min.). ARAújo, C. "Partidos políticos e gênero: mediações nas rotas de ingresso das mulheres na representação política". Revista de Sociologia e Política, no 24, p. 193-215, 2005.

"Rotas de ingresso, trajetórias e acesso das mulheres ao Legislativo: um estudo comparado entre Brasil e Argentina". Revista Estudos Feministas, vol. 18, no 2, p. 567-584, 2010.

Araujo, C. M.; Costa, S. F.; Fittipaldi, Í. "Boa noite, e boa sorte: determinantes da demissão de ministros envolvidos em escândalos de corrupção no primeiro governo Dilma Rousseff". Opinião Pública, vol. 22, no 1, p. 93-117, 2016.

Ås, B. The five master suppression techniques. In: EVENGÅRD, B. (ed.). Women in white: the European outlook. Stockholm: Stockholm City Council, p. 78-83, 2004.

BAUCKHAGE, C. Insights into internet memes. Proceedings Fifth International Association for the Advancement of Artificial Intelligence: Conference on Weblogs and Social Media. Bonn, 2011. Disponível em: <https://www.aaai.org/ocs/index.php/ICWSM/ICWSM11/paper/view/2757/3304>. Acesso em: 6 jun. 2017.

Beauvoir, S. O segundo sexo: fatos e mitos. São Paulo: Difusão Europeia do Livro, 1960.

BECKER, P. V. Ciberativismo e o "Direito achado na rede": o ciberespaço como plataforma de inteligência coletiva e enfrentamentos na luta feminista. In: SouSA JúnIOR, J. G., et al. (orgs.). Direito achado na rua. Vol. 8: Introdução crítica ao direito à comunicação e à informação. Brasília: FAC-UnB, p. 306-316, 2017.

Berger, J. Modos de ver. Rocco: Rio de Janeiro, 1999.

BERGER, P. O riso redentor: a dimensão cômica da experiência humana. Petrópolis: Vozes, 2017.

BERGSON, H. O riso: ensaio sobre a significação da comicidade. São Paulo: Martins Fontes, 2004.

BezerRA, H. D.; Mundim, P. S. "Qual foi o papel das variáveis midiáticas na eleição presidencial de 2010?". Opinião Pública, vol. 17, no 2, p. 452-476, 2011.

BORDo, S. Twilight zones. Berkeley/Los Angeles/London: University of California Press, 1999.

BRAGA, M. S. S.; CASAlECCHI, G. A. "Vencedores e perdedores nas eleições presidenciais de 2014: o efeito da derrota nas urnas sobre a satisfação e o apoio em relação à democracia no Brasil". Opinião Pública, vol. 22, no 3, p. 550-568, 2016.

BRAH, A. "Diferença, diversidade, diferenciação". Cadernos Pagu, no 26, p. 329-376, 2006.

BURROUGHS, B. "Obama trolling: memes, salute sandan agonistic politics in the 2012 presidential election". The Fibre Culture Journal, vol. 22, p. 258-277, 2013. 
GÊNERO E HUMOR NAS REDES SOCIAIS: A CAMPANHA CONTRA DILMA ROUSSEFF NO BRASIL

BUTLER, J. Gender trouble: feminism and the subversion of identity. New York: Routledge, 1999.

CAMPoS, L. A.; Miguel, L. F. "O 8 de março no Congresso: representações da condição feminina no discurso parlamentar". Cadernos Pagu, no 31, p. 471-508, 2008.

Certeau, M. A invenção do cotidiano: artes de fazer. Rio de Janeiro: Vozes, 1996.

CHAGAS, V., et al. "A política dos memes e os memes da política: proposta metodológica de análise de conteúdo de memes dos debates eleitorais de 2014". Intexto, Porto Alegre, no 38, p. 173-196, 2017.

FEDERICI, S. Calibã e a bruxa: mulheres, corpo e acumulação primitiva. São Paulo: Tradução Coletivo Sicorax, 2004.

FerreirA, C. B. C. "Feminismos web: linhas de ação e maneiras de atuação no debate feminista contemporâneo". Cadernos Pagu, Campinas, no 44, p. 199-228, 2015.

FinAmore, C. M.; CARvalho, J. E. C. "Mulheres candidatas: relações entre gênero, mídia e discurso". Revista Estudos Feministas, vol. 14, no 2, p. 347-362, 2006. Disponível em:

<http://www.scielo.br/pdf/ref/v14n2/a02v14n2.pdf>. Acesso em: 6 jul. 2017.

FREIRE, F. "Uma breve reflexão sobre memes políticos, humor e conversação cotidiana informal". Em Debate, Belo Horizonte, vol. 8, no 6, p. 34-40, 2016.

Gadsby, H. (rot.). Nanette. Espetáculo de stand-up. Dist. Netflix. Austrália, 2017 (69 min.).

Hooks, B. Talking back: thinking feminist, thinking black. Canada: Between the Lines, 1989.

LOPES, P. C. "'As expressões nervosas da presidente': estereótipos de gênero na revista IstoÉ e a repercussão com a hashtag \# IstoÉMachismo". XXXIX Congresso Brasileiro de Ciências da Comunicação, 2016. Disponível em:

<http://portalintercom.org.br/anais/nacional2016/resumos/R11-0893-1.pdf>. Acesso em: 8 set. 2018.

MARQues, F. P. J. A.; AQuino, J. A.; MiolA, E. "Parlamentares, representação política e redes sociais digitais: perfis de uso do Twitter na Câmara dos Deputados". Opinião Pública, vol. 20, no 2, p. 178203, 2014.

Miguel, L. F. "Perspectivas sociais e dominação simbólica: a presença política das mulheres entre Iris Marion Young e Pierre Bourdieu". Revista de Sociologia e Política, vol. 18, no 36, p. 25-49, 2010.

Miguel, L. F.; Biroli, F. "Mídia e representação política feminina: hipóteses de pesquisa". Opinião Pública, vol. 15, no 1, p. 55-81, 2009.

Miguel, L. F.; FeitosA, F. "O gênero do discurso parlamentar: mulheres e homens na tribuna da Câmara dos Deputados". Dados, Rio de Janeiro, vol. 52, no 1, p. 201-221, mar. 2009.

Miguel, L. F.; MARQUeS, D.; MACHAdo, C. "Capital familiar e carreira política no Brasil: gênero, partido e região nas trajetórias para a Câmara dos Deputados". Dados, vol. 58, n 3, p. 721-747, 2015.

MISKOLCI, R. "Novas conexões: notas teórico-metodológicas para pesquisas sobre o uso de mídias digitais". Cronos, vol. 12, no 2, p. 9-22, 2011.

Nicolau, J. "Determinantes do voto no primeiro turno das eleições presidenciais brasileiras de 2010: uma análise exploratória". Opinião Pública, vol. 20, nº 3, p. 311-325, 2014. 
FAGNER CARNIEL; LENNITA RUGGI; JÚLIA DE OLIVEIRA RUGGI

PANKE, L. Campanhas eleitorais para mulheres: desafios e tendências. Curitiba: Editora UFPR, 2016.

PANKE, L.; IASULAITIS, S. "Mulheres no poder: aspectos sobre o discurso feminino nas campanhas eleitorais". Opinião Pública, vol. 22, no 2, p. 385-417, 2016.

PHILliPs, A. "O que há de errado com a democracia liberal?". Revista Brasileira de Ciência Política, Brasília, no 6, p. 339-363, 2011.

RECUERO, R. "O Twitter como esfera pública: como foram descritos os candidatos durante os debates presidenciais do $2^{\circ}$ turno de 2014?". Revista Brasileira de Linguística Aplicada, vol. 16, n 1, p. 157180, 2016.

ReCuero, R.; BitTencourt, M. C. A.; ZAGo, G. "O discurso de veículos jornalísticos e a repercussão da audiência no Twitter sobre os protestos de 15 de março de 2015 no Brasil". Intercom: Revista Brasileira de Ciências da Comunicação, vol. 39, n 3, p. 115-134, 2016.

RENNÓ, L.; AMES, B. "PT no purgatório: ambivalência eleitoral no primeiro turno das eleições presidenciais de 2010". Opinião Pública, vol. 20, nº 1, p. 1-25, 2014.

RENTSCHLER, C. A.; Thrift, S. C. "Doing feminism in the network: Networked laughter and the 'Binders Full of Women' meme". Feminist Theory, SAGE Journals On-line, vol. 16, no 3, p. 329-359, Dec. 2015. Artigo publicado pela primeira vez on-line em: 18 set. 2015.

REZENDE, D. L. "Desafios à representação política de mulheres na Câmara dos Deputados". Revista Estudos Feministas, vol. 25, no 3, p. 1.199-1.218, 2017.

RochA, N. G.; BAPTISTA DA SilvA, P. V. "Representação do negro na publicidade paranaense - o 'olhar' sobre as agências publicitárias". Núcleo de Estudos Afro-Brasileiros Neab-UFPR, Curitiba, 2006.

Rossı, T. C. "Feminilidade e suas imagens em mídias digitais: questões para pensar gênero e visualidade no século XXI". Tempo Social, vol. 29, no 1, p. 234-255, 2017.

SACCHET, T. "Capital social, gênero e representação política no Brasil". Opinião Pública, vol. 15, no 2, p. 306-332, 2009.

Segurado, R. "A agenda da multidão e o webativismo na cidade de São Paulo". História Ciências Saúde Manguinhos, vol. 22, supl., p. 1.673-1.691, 2015.

SHIFMAN, L. Memes in digital culture. Cambridge: MIT Press, 2014.

TosolD, L. Do problema do essencialismo a outra maneira de se fazer política. In: BIROLI, F.; MIGUEL, L. F. (orgs.). Teoria política e feminismo: abordagens brasileiras. Vinhedo: Horizonte, p. 189-209, 2012.

VICENTE, D.; MARIA, L. "Histórias insurgentes: feministas vadias e tecnologias digitais". Esferas: Revista Interprogramas de Pós-Graduação em Comunicação do Centro-Oeste, ano IV, vol. 4, no 7, p. 163-172, 2015.

Young, I. M. "Representação política, identidade e minorias". Lua Nova, no 67, p. 139-190, 2006.

2012. . "Thinking about women as a social collective". Signs, vol. 19, no 3, p. 713-738, [1994] . "Desafios ativistas à democracia deliberativa". Revista Brasileira de Ciência Política, no 13, p. 187-212, 2014. 


\begin{abstract}
Gender and humor in social networks: the campaign against Dilma Rousseff in Brazil

This article has as an analytical corpus a set of 69 memes opposed to Dilma Rousseff that viralized in the Brazilian web between the period of June 2014 and August 2016 and investigates the contents mobilized during the public campaign in favor of the parliamentary coup occurred in Brazil in 2016. The analysis of these productions, as tools in the political disputes that culminated in the coup, is a way of interpreting the contemporary dynamics of Brazilian politics and the very place given to the figure of women and the feminine in public space. The collected memes show that comedy is built largely on gender inequalities and by not problematizing such an underlying framework we reinforce it. As an analytical strategy, we propose the classification of memes into four interpretive keys inspired by feminist political theory: (1) Depersonalization or invisibility, (2) Humiliation or ridicule, (3) Objectification or sexualization, and (4) Aggression or violence. By identifying the devices that support comedy from shared discursive parameters, the research demonstrates how the generalized dimension of political humor has mobilized sexist and misogynist stereotypes that have not only struck Dilma Rousseff but have reinforced the very symbolic place of women in national politics.
\end{abstract}

Keywords: Dilma Rousseff; gender; humor; social networks; political representation

\title{
Resumen
}

Género y humor en las redes sociales: la campaña contra Dilma Rousseff en Brasil

Este artículo tiene como corpus analítico un conjunto de 69 memes opuestos a Dilma Rousseff que se viralizaron en la web brasileña entre junio de 2014 y agosto de 2016 e investiga los contenidos movilizados durante la campaña pública a favor del golpe parlamentario ocurrido en Brasil en 2016. El análisis de estas producciones, como herramientas en las disputas políticas que culminaron en el golpe, es una forma de interpretar la dinámica contemporánea de la política brasileña y el lugar que se le da a la figura de la mujer y lo femenino en el espacio público. Los memes recopilados muestran que la comedia se basa en gran medida en las desigualdades de género y, al no problematizar ese marco subyacente, lo reforzamos. Como estrategia analítica, proponemos la clasificación de los memes en cuatro claves interpretativas inspiradas en la teoría política feminista: (1) Despersonalización o invisibilidad, (2) Humillación o ridículo, (3) Objetivización o sexualización, y (4) Agresión o violencia. Al identificar los dispositivos que respaldan la comedia a partir de parámetros discursivos compartidos, la investigación demuestra cómo la dimensión generificada del humor político ha movilizado estereotipos sexistas y misóginos que no solo han golpeado a Dilma Rousseff sino que han reforzado el lugar simbólico de la mujer en la política nacional.

Palabras-clave: Dilma Rousseff; género; humor; redes sociales; representación política

\section{Résumé}

Genre et humour dans les réseaux sociaux: une campagne contre Dilma Rousseff au Brésil

Ayant pour objet d'analyse un jeu de 69 mèmes contraires à Dilma Rousseff qui a viralisé sur le web brésilien entre la période de juin 2014 et août 2016, cet article enquête sur les contenus activés lors de la campagne publique en faveur du coup d'État parlementaire survenu au Brésil en 2016. Regarder ces productions, comme outils dans les conflits politiques qui ont abouti au coup, peut être une manière d'interpréter la dynamique contemporaine de la politique brésilienne et la place accordée à la figure de la femme et du féminin dans l'espace public. La collection recueillie révèle que la comédie se construit, dans une large mesure, sur les inégalités entre les sexes et, en ne remettant pas en question un tel cadre sous-jacent, les renforce. En tant que stratégie analytique, nous proposons de classer les mèmes en quatre clés interprétatives inspirées de la théorie politique féministe: (1) dépersonnalisation ou invisibilisation, (2) humiliation ou ridiculisation, (3) objectivation ou sexualisation et (4) agression ou violence. En identifiant les dispositifs prenant en charge la comédie à partir de paramètres discursifs partagés, la recherche démontre comment la dimension genrée de I'humour politique a mobilisé des stéréotypes sexistes et misogynes qui n'ont pas seulement frappé Dilma Rousseff, mais ont renforcé la place très symbolique des femmes dans la politique nationale.

Mots-clés: Dilma Rousseff; genre; humour; réseaux sociaux; représentation politique

Artigo submetido à publicação em 3 de novembro de 2017. Versão final aprovada em 29 de outubro de 2018.

Opinião Pública adota a licença Creative Commons CC-BY.

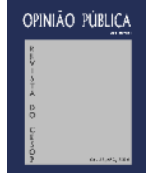

